\title{
MODEL OF INTEGRATED ACADEMIC PERFORMANCE AND ACCOUNTABILITY SYSTEM FOR HEI
}

\section{SHAWYUN TEAY}

\begin{abstract}
:
While accountability has been discussed and designed for implementation for schools systems in the West, what would responsibility and accountability mean for a Higher Education Institute (HEI) has been elusive. Basically, key literature in accountability connects assessment, teaching and learning, student and teacher systems, testing systems leading to improvements, innovations and renewals in the whole organizational capacity and capabilities system. These basically are the 4 sanctified mission tenets of any $\mathrm{HEl}$ of teaching, learning, research and societal responsibility. A key question facing most $\mathrm{HEl}$ would be the fundamental principles and mechanics in developing, ensuring and measuring these accountabilities that affects the students and society. The immediacy is the internal policies, processes, pragmatics and practices of the creation and delivery of "education value" that is the faculty and staff using the educational processes responsibly and accountably way towards the students' accomplishment and achievements and societal development. Instead of focusing on the outcome of the accountability from external measures, this paper will focus on the internal practices and mechanisms that need to be established to ensure and support to internal responsibility and accountability of the $\mathrm{HEl}$ and its academic personnel. This paper aims at proposing a working model for this internal integrated Academic Performance and Accountability System (APAS) for a HEl. Six key internal indices are established in the key areas to course evaluations index, teaching and learning assessment learning outcome index of student, quality contributions index, research index, administrative work index, societal responsibility index. All these culminate in the Academic Performance and Accountability Index (APAI) of a scorecard of the faculty performance and accountability from the inherent internal processes that affect the final student external outcome performance.
\end{abstract}

\section{Keywords:}

Academic accountability, higher education, balanced scorecard approach, academic performance and evaluation

JEL Classification: 121

\section{Authors:}

SHAWYUN TEAY, King Saud University, Saudi Arabia, Email: jerry182122@yahoo.com

\section{Citation:}

SHAWYUN TEAY (2015). Model of Integrated Academic Performance and Accountability System for HEI. International Journal of Teaching and Education, Vol. III(2), pp. 50-72.,

10.20472/TE.2015.3.2.004 


\section{Rationale of the HEI - APAS}

An educational institution has a great responsibility towards society in developing a competent "total" graduate who is competent and qualified physically, intellectually, mentally, socially, spiritually and ethically for the market and societal development and wellbeing. The academics' dedication and commitment is enshrined in the academics' responsibility and accountability to create and deliver on educational value to develop the "total" graduate outcomes. While HEls aim to be world class, they need highly qualified and competent academics that are dedicated and committed to the dreams of HEls. Commitment must be accountable, as commitment without accountability is a futile and useless dream and action for any faculty. At the same time, the competency and commitment should be measured and these measures have been rather elusive. Most schools and institutions prefer to look at the end outcome achievements measures like the performance in external standardized test like the SAT or professional licensing in specialized areas of professions like the medical boards or engineering board or teaching profession licenses.

HEls need dedicated and committed academics that are responsible and accountable for their accomplishment and achievements towards the stakeholders and society. While most of us look at the external measures, they overlooked a key area whether these final external outcomes are created and delivered by the internal people and processes. As such, it is strongly recommended that the HEl should set up an internal system where these performances and accountabilities are measured. These should be measured and improved on over the 4 years education process by the proficiencies of the faculty starting from the moment the student join the HEI up to the moment when the student leave the $\mathrm{HEI}$ education system. With this in mind, this paper propounds that the HEl set up an internalized HEI - APAS (HEI Academic Performance and Accountability System) as a way and mean to ensure that dedicated and committed academics that perform are accountable for their actions in line with HEl's aim to be a world class university.

In the internalized education process, two key areas that constitute the major areas of responsibilities and accountabilities of a faculty are in the teaching and learning in each course, where there are indirect assessment via the course satisfaction survey and the Student Learning Outcome (SLOs) assessment through various assessment methodologies. Another key area is the definition and management of the term course assignment taught and measured for performances which are reflected in the course specifications and the course reports that are prepared at the beginning and end of the term respectively. All these are reported and reconciled for proactive actions and improvements. Another key measure is the faculty research contribution which can be used as improvement on the course content and context. While faculties think that their sole responsibility is in teaching, learning and research, another part of their responsibility is towards their program and college administrations and societal responsibilities. These two constitutes two indirect areas of performance and accountabilities that needs to be constituted as the overall performance and accountability of the faculty. Basically, these 6 areas are used as the basis of the creation of the APAI (Academic Performance and Accountability Index) and its scorecard in the APAS as proposed in this paper. 


\section{Perspectives of Accountability in Education}

In earlier literature on accountability, Levin (1974) identified 4 distinct concepts of accountability as:

1) Performance reporting - This is aimed at the educational outcomes and its proficiencies that can be appraised by the constituents,

2) Technical process - This deals with the technical approaches for delivering educational services or evaluating the operations of schools in the context of managerial decision making (like incentives structure, personnel arrangements, performance contracting, evaluation and decision making mechanisms that leads to establishment of standards of expected students' progress and mechanisms of assessment, assessment of certified personnel competence and other duties in addition to regular assignments and establishment of procedures and techniques to ascertain that the certified personnel is maintaining proper control and preserving a proper learning environment, all of which leads to "educational performance contracting",

3) Political process - This aims at meeting the implicit or explicit needs of very different and diverse groups,

4) Institutional process - This is based on the beliefs of overhauling the society to allow greater participation and equality so that schools can promote more productive and equitable goals.

In his book, "A new model for school accountability", Ken Jones (2006) proposed a new model that focuses on the school as an institution itself that should be accountable to its customers in the areas of:

- The Physical and Emotional Well-Being of Students - Schools should be accountable for maintaining such warm and inviting human environments.

- Student Learning and Assessment - Student learning is complex and multifaceted, not something that can be well gauged with one simple standardized test. The local assessment component that addresses local curricula, contexts, and cultures should be added as a large-scale external test is simply not sufficient to determine a student's achievement.

- Teacher Learning and Evaluation - Good teaching supports and enables good learning and having a knowledgeable and skilled teacher is crucial. Schools must be provided with sufficient time and funding, and held accountable, for guiding teachers to improve their own performance, according to professional teaching standards. Evaluation must be done in a way that honors democratic processes, supports the teaching profession, and upholds high standards of performance.

- Improving and Renewing - Schools needs to be dynamic learning organizations, continuously engaged in self-assessment and adjustment with respect to meeting the needs of their students. The school capacity to change structures and norms may need to be changed and new ends and means may need to be reconsidered to develop a professional learning community, of which the school should be accountable, and is necessarily an ongoing effort.

Jones (2006) noted that the professional community in the school must take responsibility for developing goals and priorities based on the ongoing collection and analysis of data, monitor its performance, and report its findings and actions to its 
public. Many schools have not moved past the condition where individual teacher responsibility rather than collective responsibility is the norm, which is the "organization capacity". Jones (2004) also argued that a balanced model or "balanced scorecard" to be applied to education with the following aspects of school performance as the components of a balanced school accountability model can be used: (1) student learning; (2) opportunity to learn; (3) responsiveness to students, parents, and community; and (4) organizational capacity for improvement. (3) and (4) supports Porter and Chester's (2001) view of shared responsibilities across the stakeholders of students, faculty, administrators and policy makers through incentives.

Middaugh, (2007) stated that "the central core of a university mission statement has to be the teaching and learning process, and it is incumbent for the institution to show evidence that student learning is taking place" and governmental and accreditation agencies are demanding increasing accountability and efficiency from universities on such. All these are anchored in the Standards and Criteria requirements of the accreditation internal quality management system and mechanisms of the HEI (Higher Education Institution). Proficiencies of the students' achievement in learning were defined in a 6 level "Proficiency Index Scores" (Linn, 2003) as used by the Colorado, New York and Massachusetts and other Schools Systems in the US based on standardized test scores. Malandra (2008) concluded that "accountability and assessment work connects" and "the new generation of accountability, assessment and testing must focus on analysis and improvements, not punishment and not high stakes", with all information embedded at all levels - in academic programs, institutional planning and accountability reports.

Basically, the key literature in accountability connects assessment, teaching and learning, student and teacher systems, testing systems leading to improvements, innovations and renewals in the whole organizational capacity and capabilities system. All of these connects and affects the "organizational capacity and human capabilities" leading to the organizational capacities and human competencies which develops and designs evaluation and assessment systems that creates and delivers on value to the students. All these mean that the organization and its human system "capacities and capabilities" and internal processes are what the HEl should be responsible and accountable for.

\section{Accountability System within the HEI context}

In retrospect, the US has had about half a century of developmental knowledge and skills in assessment and about two decades of experience in identifying and developing accountability of the school systems. The US Schools Systems accountabilities have progressed into the HEl environment which has created many perspectives and approaches albeit being contentious and diverse in nature. A key aspect is the strong support and leadership from national policy makers to ensure accountabilities after having established a stronger foundation in assessment leading to accreditation in all the US territories. National or State levels infrastructures and polices supported these development and the call for its accountability of the schools systems to its stakeholders.

On the other hand, in Kingdom of Saudi Arabia (KSA), or in other third world or emerging economies it might still be in an emerging or pre or infantile stage for a national focus or directional impetus from national policy makers. As evidenced in the accreditation moves in KSA, it could take a longer time for KSA to reach the maturing 
stage of the US accreditation progress. Under this scenario, the HEI has the option to wait for national directions, or the HEl can opt to start off its own accountability system.

It is the aim of this proposal to recommend for the HEI to learn from the wider good practices of the US experience and develop the first stage of its accountability system focused on its key resources that has a potentially high impact on the students' outcomes. It can be a two pronged strategy as assessment and accountability connects (Malandra, 2008; Jones 2004 and 2006) through the following:

a. Assessment system - This is enshrined and established in its overarching $\mathrm{HEI}$ - QMS (Quality Management System) that are inclusive of its 3 phases of self-study, internal audit and assessment and developmental planning, all of which have core audit and assessment of Student Learning and Assessment and Teacher Learning and Evaluation that brings about Improving and Renewing (Middaugh, 2007; Jones 2004 and 2006).

b. Accountability system - This should initially be focused on the human capacity and capabilities as it is a critical resource that affects students learning, opportunities to learn and being responsive to the students' needs (Jones 2004 and 2006) and that leads to Improving and Renewing (Middaugh, 2007; Jones 2004 and 2006). All these would have an impact on a future Students' Proficiency Index that can be developed in a later phase when there are more emergent national polices (Linn 2003, Teay 2005).

\section{Rubrics of a HEI - APAS (Academic Performance and Accountability System)}

Based on the proposed approach for the HEl as noted, the organizational capacity and human competencies that brings about the responsibilities and accountabilities of the "organizational actions" and "human actions and activities" to create and delivers educational value appears to be a basic parameter that should be used as one of the key determinant in the HEI "organizational accountability system". This would be the focus of this proposal. 


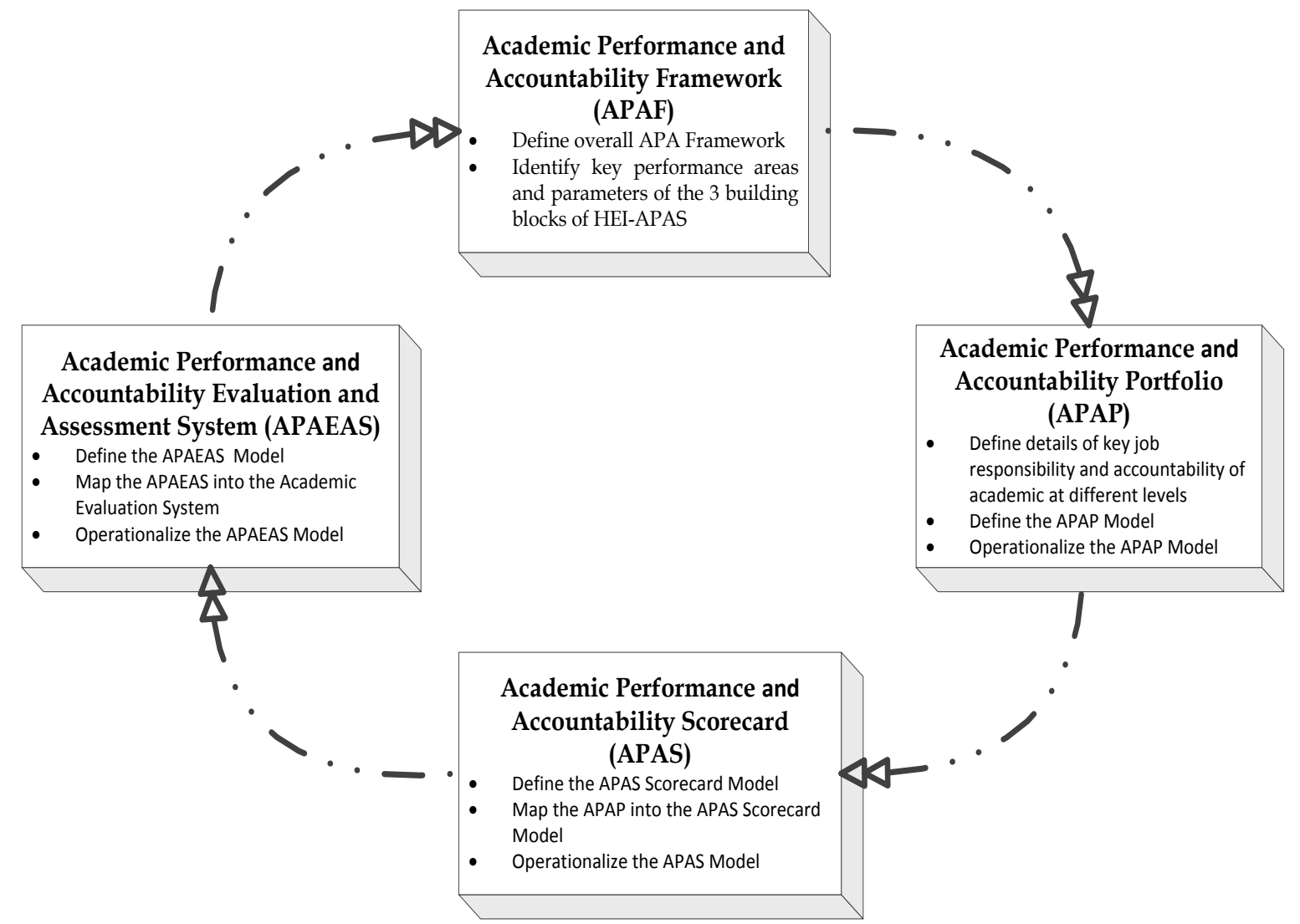

Using this as the key premise, the Figure 1 above shows the key building blocks of the $\mathrm{HEI}$ - APAS (Phase 1 Development) which is divided into 4 main components of the:

1. Academic Performance and Accountability Framework (APAF) - This main framework component will define the argument for the HEI-APAS conceptual framework that will later be operationalized into its detailed specifications of the supporting building blocks of the APAS portfolio, the APAS Scorecard and the APAS Evaluation and Assessment system for each of the academic in its discharge of its responsibilities to create and deliver on educational value leading to the students' outcomes.

2. Academic Performance and Accountability Portfolio (APAP) - This component defines the academic portfolio specifications that collates, compiles and documents all his/her personal data, research publications, academic and advising workload, students' projects/thesis advising, academic and societal services, administrative work, academic or administrative representations outside of institution, and etc. These are based on the 4 main pillars of an academic mission of teaching-learning, research, administration and social contributions.

3. Academic Performance and Accountability Scorecard (APAS) - This component defines the personal performance scorecard of the academic based on the rubrics defined in the APAP together with the linkage to the school or program scorecard, and the academic's expected and actual achievement of the goals set for each academic year. This could be consolidated into the overall Collegial or Institutional Academic and Accountabilities performance 
scorecard, all of which are aligned with their strategic objectives cascaded at all levels. The basic concept is that each individual academic has an individualized performance scorecard which can be alluded to be the "personal contractual agreement" to perform.

4. Academic Performance and Accountability Evaluation and Assessment System (APAEAS) - This component defines the evaluation and assessment specifications and mechanisms that are based on the accomplishment and achievements of the each of the individual APAI (Academic Performance and Accountability Index) Scorecard. This is ultimately tied to the annual performance evaluation of an academic affecting his/her promotion or annual increment or other benefits like sabbatical, travels entitlements or others as deemed appropriate. This can be alluded to a 360 degree "performance-based evaluation and assessment" or "merit-based" system for monitoring and managing each academic individual performance.

\section{HEI - APAP Specifications}

In the HEI - APAP system, the key component is the individual faculty portfolio which collates and constitutes the work assignment and accomplishment of a typical faculty for an academic year. Normally there are 7 main key areas where the faculty life is evolved around in:

1. Description of Teaching work load and assessment - This includes all the different courses and sections that the faculty is assigned each term, where the key document is the Course Specifications (CS) and Courses Reports (CR). In the CS and CR, the key areas of assessment or the assessment rubrics of the student learning outcomes to accomplish the course objectives are documented and evaluated for performance. The normal tools used are the direct measures of SLOs assessment for accomplishment is the assessment rubrics for the different teaching strategies or methodologies used. The indirect measures are the course survey done at the end of each course for each term. These two are actually the key focus related to the final student outcome measure.

2. Advising - This constitutes the normal administrative activities of the faculty in the form of the normal advising workload per faculty per semester/term which is considered as part of the load of faculty.

3. Dissertation/Thesis/Independent Studies/Senior Project Advising - This constitute the academic advising part of the research or capstone or senior project, inclusive of the masters and doctoral thesis or dissertations, which constitute part of the faculty performance evaluation.

4. Research and Academic Work Publications OR Creative Works OR Patents - This constitute a key mission of the faculty in his or her research accomplishment and achievements that further the knowledge contribution to the course improvements or for use for societal development.

5. Professional Development - This constitutes the performance development of the faculty through various developmental mechanisms like seminars, professional meetings, trainings, workshops or conferences.

6. Additional Work Assignments - This will constitute additional works as assigned or contributed like being a member of the program quality committee, academic committee, societal responsibility committee, or any ad hoc 
committees at the institution level to perform certain assignments contributing to the program or the college development.

7. Academic Services and Societal Responsibilities - This constitutes the additional academic services that are rendered to the external stakeholders groups or the communities. This could range from paid consultancies or unpaid services to the communities like free educational services, workshops, communities' projects or serving of advisory bodies for the betterment of society ad community. This comprises also the Academic or Professional Awards that includes all types of recognitions or awards that the faculty receives in recognition of development or performance by the internal or external bodies. This can normally be included in the academic services and societal responsibilities where the faculty is recognized or awarded for his/her achievements.

Basically, the bottom line is that these must be defined clearly and carefully as they form the basis of responsibility and accountability in the job description and requirement of the faculty. This will be the framework where the faculty performance is evaluated and assessed based on the key dimensions as defined in the faculty portfolio of responsibilities.

\section{HEI - APAS specifications}

With the seven key areas of the faculty portfolio of responsibilities defined in the HEI - APAP, this is converted and mapped into a faculty performance and accountability indices that constitutes the performance indices and performance scorecard in the $\mathrm{HEl}$ - APAS. The seven main key areas of responsibilities (Appendix 1) are converted into six main dimensions of performance and accountability indices as follows:

1. Course Qualitative Survey based Evaluations Performance (10 points) Appendix 1(1) typifies the normal qualitative course survey that is conducted as an indirect assessment of the perception of the teaching and learning performance at the completion of each course in each term. The key is the categorical dimensions of these statements that could provide a rich qualitative satisfaction dimension of each categorical and determine the existence of any gap of "actual performance" and "expected performance". An average \% mean score is computed as the Course Evaluation Index (Table 3) based on the band performance rubrics (Table 1).

2. Course Direct Assessment Student Learning Outcome (SLO) Performance (20 points) (Appendix 1(2)) - While qualitative surveys have been utilized to determine the satisfaction level of each course, direct assessment of accomplishment and achievement of the student learning outcomes using the different teaching assessment methodologies like quizzes, assignments, presentations, capstone project, class discussions, examinations, etc., with the level of accomplished of the SLOs as per the performance band (Table 1) as shown below: 


\section{Table 1: Rubrics of Band performance for Student Learning Outcome}

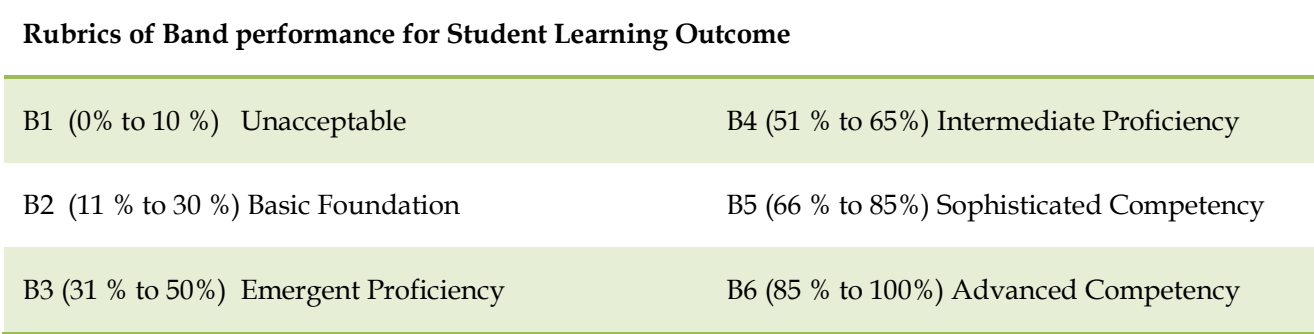

\section{Table 2: Band Performance of the Course CS 101 based on the SLOs assessment rubrics}

\begin{tabular}{|c|c|c|c|c|c|c|}
\hline $\begin{array}{l}\text { Course } \\
\text { Code }\end{array}$ & $\begin{array}{l}\text { Course } \\
\text { Title }\end{array}$ & $\begin{array}{l}\text { Competencies } \\
\text { Dimension }\end{array}$ & $\begin{array}{l}\text { Final } \\
\text { Examination }\end{array}$ & $\begin{array}{l}\text { Capstone } \\
\text { Project }\end{array}$ & Case Study & $\begin{array}{l}\text { Overall Band } \\
\text { Performance }\end{array}$ \\
\hline \multirow{8}{*}{$\begin{array}{l}\text { Introduction } \\
\text { to Computer } \\
\text { Science }\end{array}$} & \multirow[t]{8}{*}{ CS 101} & Knowledge & $75 \%$ & $85 \%$ & $80 \%$ & $80 \%$ \\
\hline & & Cognitive Skills & $70 \%$ & $70 \%$ & $75 \%$ & $73 \%$ \\
\hline & & $\begin{array}{l}\text { Critical \& Analytical } \\
\text { Skills }\end{array}$ & $40 \%$ & $45 \%$ & $45 \%$ & $40 \%$ \\
\hline & & $\begin{array}{l}\text { Interpersonal } \mathcal{E} \\
\text { Entrepreneurial Skills }\end{array}$ & NA & $55 \%$ & $50 \%$ & $52 \%$ \\
\hline & & $\begin{array}{l}\text { Professional Ethics, } \\
\text { Morals \& Values }\end{array}$ & NA & $75 \%$ & $75 \%$ & $75 \%$ \\
\hline & & Information Literacy & NA & $65 \%$ & $70 \%$ & $67 \%$ \\
\hline & & Communication Skills & NA & $65 \%$ & $70 \%$ & $67 \%$ \\
\hline & & Psychomotor skills & NA & NA & NA & NA \\
\hline \multicolumn{3}{|c|}{ Overall SLO Competencies (SLOC) Index } & $62 \%$ & $66 \%$ & $66 \%$ & $65 \%$ \\
\hline
\end{tabular}

A sample (Table 2) is illustrated for the CS 101 Introduction to Computer Science which uses 3 main assessments methodology of Final Examination, Capstone Project and Case Study. The course objectives, based on the program objectives, have defined 7 main SLOs or competencies dimensions to be measured. Based on the band performance scoring of the SLOs rubrics, it appears that the 3 different assessment methodologies averaged $65 \%$ which is in the "Intermediate proficiency" band. On deeper analysis, it is found that the student did not fare well in two key SLO dimensions of "critical and analytical skills" and "interpersonal and entrepreneurial skills" which attained an average of $40 \%$ "emergent proficiency" and $52 \%$ which is on the low end of "intermediate proficiency". Using this analysis, the course instructor can bring about continuous improvements in the course teaching strategies to improve on these SLOs dimensions which are lacking or not faring well. With the use of information technology automation, comparative analysis can be made, and this will become a powerful decision support system to continuous improvements to ensure that the students are equipped with the competencies which are measured for performance as envisaged. Based on this 
approach, a Student Learning Outcome Competency (SLOC) Index (Table 2 and 3) is computed.

3. Quality Efforts Contribution Performance (15 points) - In the efforts to employ quality management, Appendix 1(3) takes into account the degree of responsibility of the faculty in developing the Course Specification that details on the course requirements in terms of overall course objectives / outcomes, specific student learning outcomes, teaching strategies and assessment methodologies. These are then reported for performance and analysis at the end of the term in the Course Report that includes the Table 2 above, its findings and its planned improvements for the upcoming term. While it seems laborious, it serves as a very powerful analytical and developmental tool for the determination of the faculty overall purview and reflections of his/her contribution to the students' learning outcomes accomplishment and accountability towards the students' performance. Based on this approach, a Quality Efforts Contribution Index (Table 3 ) is computed.

4. Research Contributions Performance (20 points) - As shown in Appendix 1(4), while research has been a key dimension of the faculty performance and mission in creating new knowledge, the research component should also contribute to the faculty development in the application of the findings to bring about improvements or new knowledge in the course taught. This will ultimately further develop and equip the students with the dynamics of updated knowledge as opposed to the static rote learning and memorization from text book materials. Based on this approach, a Research Contribution Index (Table 3) is computed.

5. Administrative Work Contribution Performance (15 points) - These administrative work responsibility as shown in Appendix 1(5) are more indirect contribution to the accountability through the responsibility in being assigned to certain committees, jobs that affects the students' performance indirectly. These can include the normal academic advising or thesis / dissertation / project advising. Based on this approach, an Administrative Work Contribution Index (Table 3) is computed.

6. Societal Responsibility Contribution (15 points) - As part of the faculty mission, societal responsibility in Appendix 1(6) is key performance metrics that demonstrates the faculty responsibility and accountability towards the community and society. These are normally delivered through academic services, community services, but to be effective, it should be measured for performance to avoid the "lip service" syndrome or avowal that a faculty main duty is in teaching and learning. This aspect inherently is an important conscientious effort of the faculty to look beyond their basic call of duty and work towards the benefits of the greater community. Based on this approach, a Societal Responsibility Contribution Index (Table 3) is computed.

All the above six dimensions of the academic performance and accountability indices will be tabulated on a weighted score board for each faculty, resulting in an Academic Performance and Accountability Index Scorecard (APAIS) as shown in Table 3. As not all the dimensions are equally important to the contribution of the performance and accountability index, weights are assigned to justify their important. It is important to note that the first 3 sets of indices (CEI, $\mathrm{SCl}$ and QECI) constitute $45 \%$ of the scores as they represent the student accomplishment is a major performance and accountability dimension. The Band Performance Score for each of the dimension comes from each of the indices discussed above. The weighted score in column 4 is derived from the weights*band performance score \%. The illustrated example below (Table 3) shows that the overall performance and accountability of the faculty is 61.25 which fall into Band B4 which is Average Performance. Deeper analyses on each of the contributing indices show that the lower performances are more in the administrative areas of 
the $\mathrm{QECl}, \mathrm{AWCl}$ and $\mathrm{SRCl}$, as opposed to the teaching and learning and research components.

Table 3: Academic Performance and Accountability Index (APAI) Scorecard of Faculty

Band Performance Legend
․ B1 $(0 \%$ to $10 \%)$ Poor Performance
그 (11 \% to $30 \%)$ Low Performance
口 $33(31 \%$ to $50 \%)$ Below Average
․ B4 (51 \% to 65\%) Average Performance
․ B5 (66 \% to $85 \%)$ Good Performance
․ B6 (85\% to $100 \%)$ Excellent Performance

\begin{tabular}{|l|c|c|c|}
\hline $\begin{array}{l}\text { Dimensions of Academic Performance } \\
\text { and Accountability Index (APAI) }\end{array}$ & Weights & $\begin{array}{l}\text { Band Performance } \\
\text { Score (\%) }\end{array}$ & $\begin{array}{l}\text { Overall Weighted } \\
\text { Score }\end{array}$ \\
\hline Course Evaluations Index (CEI) & 10 & $80 \%$ & 8.0 \\
\hline Student Competencies Index (SCI) & 20 & $75 \%$ & 15.0 \\
\hline Quality Efforts Contribution Index (QECI) & 15 & $65 \%$ & 9.75 \\
\hline Research Contributions Index (RCI) & 20 & $75 \%$ & 7.5 \\
\hline $\begin{array}{l}\text { Administrative Work Contribution Index } \\
\text { (AWCI) }\end{array}$ & 15 & $50 \%$ & 6.0 \\
\hline $\begin{array}{l}\text { Societal Responsibility Contribution Index } \\
\text { (SRCI) }\end{array}$ & 15 & $40 \%$ & $\mathbf{6 1 . 2 5}$ \\
\hline $\begin{array}{l}\text { Academic Performance and } \\
\text { Accountability Index (APAI) Scorecard }\end{array}$ & $\mathbf{1 0 0}$ & & \\
\hline
\end{tabular}

Note: The Overall Performance Score is from the final overall score for each of the key areas of evaluation in Parts 1 to 6.

\section{HEI - APAEAS Specifications}

\section{Table 4: Cascading of Strategic Objective on Student Performance using the SLOC Index from Institution to Program Level}

\begin{tabular}{|c|c|c|c|}
\hline HEI University & $\begin{array}{l}\text { HEI Students are competent meeting } \\
\text { the needs of the market }\end{array}$ & $S L O C$ Index of $H E I=80^{\circ}$ & \\
\hline $\begin{array}{l}\text { College of } \\
\text { Engineering }\end{array}$ & $\begin{array}{l}\text { Graduate of HEI College of } \\
\text { Engineering are equipped with the } \\
\text { knowledge and skills needed to ensure } \\
\text { their success in the job market }\end{array}$ & SLOC Index of College of & zeering $=75 \%$ \\
\hline \multirow{2}{*}{$\begin{array}{l}\text { Industrial } \\
\text { Engineering } \\
\text { Program }\end{array}$} & \multirow{2}{*}{$\begin{array}{l}\text { An Industrial Engineering graduate } \\
\text { excel in the } 7 \text { key dimensions of the } \\
\text { Student Learning Outcome Index } \\
\text { (SLOC) }\end{array}$} & $\begin{array}{l}\text { SLOC Index Competencies } \\
\text { Dimension }\end{array}$ & $\begin{array}{l}\text { Overall Band } \\
\text { Performance }\end{array}$ \\
\hline & & Knowledge & $80 \%$ \\
\hline
\end{tabular}




\begin{tabular}{|c|c|c|c|}
\hline & & Cognitive Skills & $73 \%$ \\
\hline & & Critical \& Analytical Skills & $40 \%$ \\
\hline & & $\begin{array}{l}\text { Interpersonal } \mathcal{E} \quad \text { Entrepreneurial } \\
\text { Skills }\end{array}$ & $52 \%$ \\
\hline & & Professional Ethics, Morals \& Values & $75 \%$ \\
\hline & & Information Literacy & $67 \%$ \\
\hline & & Communication Skills & $67 \%$ \\
\hline & & Psychomotor skills & NA \\
\hline & & SLOC Index of IE graduate & $65 \%$ \\
\hline $\begin{array}{l}\text { Mechanical } \\
\text { Engineering }\end{array}$ & $\begin{array}{l}\text { A Mechanical Engineering graduate } \\
\text { excel in the } 7 \text { key dimensions of the }\end{array}$ & $\begin{array}{l}\text { SLOC Competencies } \\
\text { Dimension }\end{array}$ & $\begin{array}{l}\text { Overall Band } \\
\text { Performance }\end{array}$ \\
\hline & $(\mathrm{SLOC})$ & Knowledge & $85 \%$ \\
\hline & & Cognitive Skills & $75 \%$ \\
\hline & & Critical \& Analytical Skills & $70 \%$ \\
\hline & & $\begin{array}{l}\text { Interpersonal } \mathcal{E} \quad \text { Entrepreneurial } \\
\text { Skills }\end{array}$ & $72 \%$ \\
\hline & & Professional Ethics, Morals $\mathcal{E}$ Values & $75 \%$ \\
\hline & & Information Literacy & $77 \%$ \\
\hline & & Communication Skills & $77 \%$ \\
\hline & & Psychomotor skills & NA \\
\hline & & SLOC Index of IE graduate & $78 \%$ \\
\hline
\end{tabular}

Typically, a HEI has strategic plan with strategic goals and SMART (Specific, Measurable, Achievable, Realistic and Time-framed) objectives, that are cascaded down to the college and its programs. These are normally formalized through the BSC approach where the institution scorecard is cascaded down to the college, program and individual faculty (Teay, 2012).

The above Table 4 shows that the cascading of an institutional strategic objective to the college and program are aligned and measured through the HEI student outcome to the programs' SLOC Index. The above shows that the Mechanical Engineering Program students' SLOC Index of $78 \%$ has better competencies outcome as compared to the Industrial Engineering Program SLOC Index of $65 \%$ or the College of Engineering SLOC Index internal benchmark of $75 \%$. On the other hand the overall College of Engineering SLOC Index at $75 \%$ is lower than the institutional SLOC Index of $80 \%$. 


\section{Table 5: Academic Performance and Accountability Index Scorecard Metrics of Faculty}

Band Performance Legend
․ B1 (0\% to $10 \%)$ Poor Performance
․ B2 (11 \% to $30 \%)$ Low Performance
ㄱ B3 (31 \% to 50\%) Below Average
ㄱ B4 (51 \% to 65\%) Average Performance
口 B5 (66 \% to $85 \%)$ Good Performance
口 B6 (85 \% to 100\%) Excellent Performance

\begin{tabular}{|l|c|c|c|c|c|c|}
\hline $\begin{array}{l}\text { Performance \& } \\
\text { Accountability Indices }\end{array}$ & Weights & $\begin{array}{c}\text { Overall } \\
\text { Performance } \\
\text { Score (\%) }\end{array}$ & $\begin{array}{c}\text { Actual } \\
\text { Performance }\end{array}$ & $\begin{array}{c}\text { Target } \\
\text { Performance }\end{array}$ & $\begin{array}{c}\text { Gap } \\
\text { difference }\end{array}$ & $\begin{array}{c}\text { Internal } \\
\text { Benchmark }\end{array}$ \\
\hline $\begin{array}{l}\text { Course Evaluations } \\
\text { Index }\end{array}$ & 10 & $70 \%$ & $.7 * 10=7$ & 8 & -1 & 8 \\
\hline SLOC Index & 20 & $80 \%$ & $.8 * 20=16$ & 15 & -1 & 12 \\
\hline $\begin{array}{l}\text { Quality Efforts } \\
\text { Contribution Index }\end{array}$ & 15 & $40 \%$ & $.4 * 15=6$ & 10 & -4 & 12 \\
\hline Research Contributions & 20 & $70 \%$ & $.7 * 20=14$ & 15 & 12 \\
\hline $\begin{array}{l}\text { Administrative Work } \\
\text { Contribution Index }\end{array}$ & 15 & $50 \%$ & $.5 * 15=7.5$ & 10 & -2.5 & 12 \\
\hline $\begin{array}{l}\text { Societal Responsibility } \\
\text { Contribution Index }\end{array}$ & 15 & $40 \%$ & $.4 * 15=6$ & 10 & -4 & 76 \\
\hline $\begin{array}{l}\text { Performance \& } \\
\text { Accountability Index }\end{array}$ & 100 & & 56.5 & 68 & -11.5 & 72 \\
\hline
\end{tabular}

In the Academic Performance and Accountability Evaluation and Assessment System (APAEAS), the APAI Scorecard (Table 5) for each of the individual faculty is used as the basis of a 360 degree performance evaluation of the faculty from the direct superior, peer, subordinate (if any) and the faculty himself or herself, as used in most human resources performance evaluation system. Table 5 shows an example of the APAI of an individual faculty. In the faculty performance evaluation, the faculty sets a target for each of the APAI at the beginning of the term, collate and compute the actual score of the APAI. It shows that other than research, the faculty is underperforming in all aspects of his/her academic performance and accountability with a gap difference of -11.5 points. This shows that as compared to his/her peer, the faculty's performance at 68 points is below par of the aggregated internal benchmark of 76 points (which can be the median score or the means averaged score). The APAI could provide a degree of evaluation of the performance where the faculty can identify areas that need improvements and actions can be taken based on the individual analysis and reflections by the faculty that can bring about an action plan for improvement. This could lead to a better developmental planning of ways and means to improve on these deficient areas of performance and accountabilities. 
Table 6: 360 degree APAl evaluation of an individual faculty

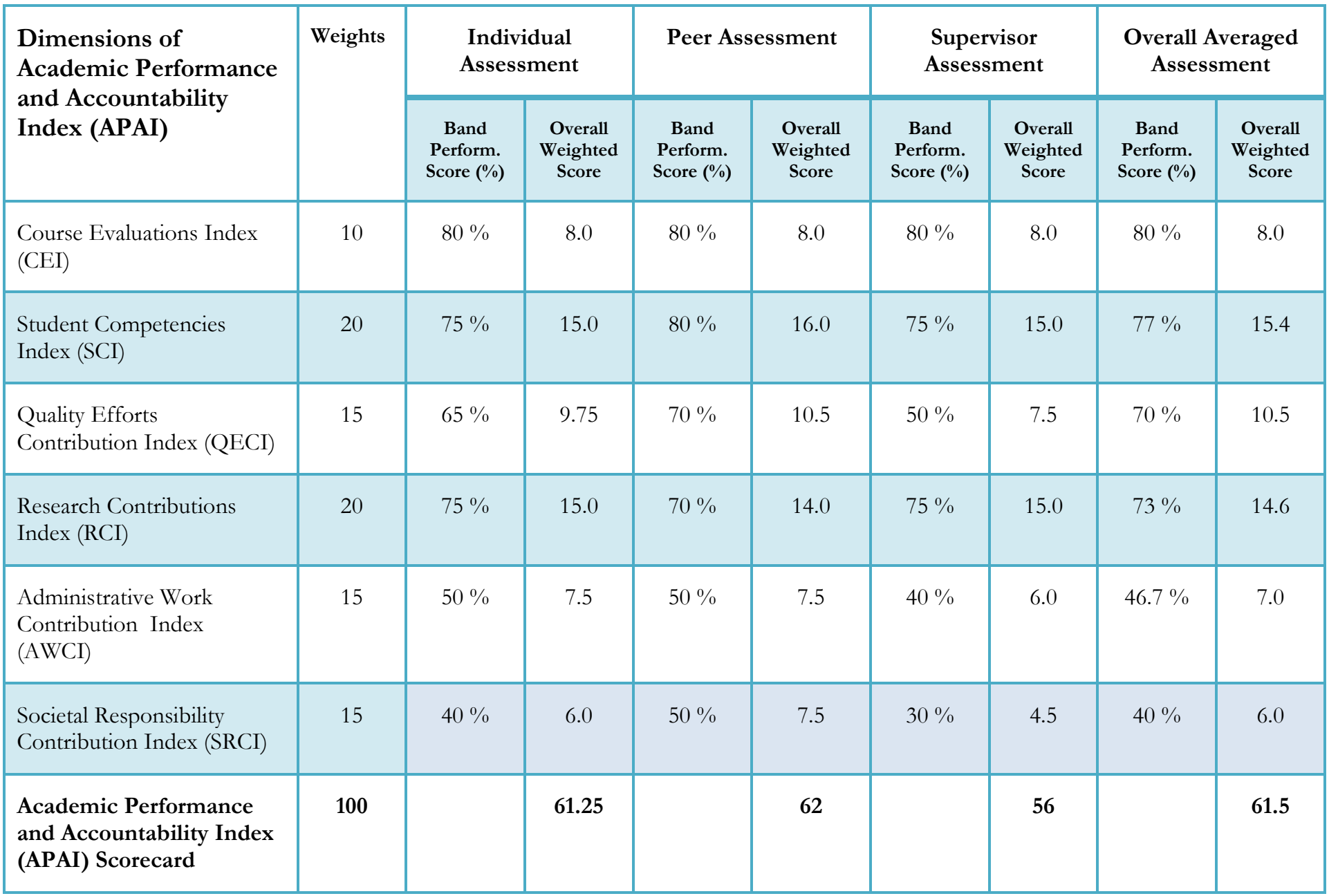

At the same time, the faculty term or annual performance can be evaluated using a 360 degree performance evaluation by the faculty himself/herself, his/her peer and the supervisor. In Table 6, it shows that relatively the peer provided a similar 62 point score on the APAI but the supervisor provided an evaluation of 56 points on the APAI which is much lower that the individual and peer evaluation. But when averaged out, the overall score is 61.5 is very near to the individual and peer evaluation. This could allude to the questioning of the supervisor's performance scoring which is skewed towards the lower end in the QCEI, AWCI and SRCl which are mostly in the administrative supporting indirect activities rather than the direct activities of the $\mathrm{CEI}$, $\mathrm{SCI}$ and QCEI. This overall approach in using the 360 degree performance of the use of the APAI in assessing the performance and accountability of a faculty through a more constructive and unbiased but justifiable to show the overall performance evaluation and identify areas for improvements as opposed to the normal qualitative evaluation methodologies used. 
Table 6: Cascading of Strategic Objective on Faculty Performance and Accountability using the APAI from Institution to Program Level

A Strategic Objective for the determination of the Faculty Performance and Accountability based on the APAI (Academic Performance and Accountability Index)

\begin{tabular}{lll} 
HEI & APAI of $H E I=85$ points score \\
University & $\begin{array}{l}\text { HEI Faculty are } \\
\text { accountable meeting the } \\
\text { needs of the stakeholders }\end{array}$ \\
\hline $\begin{array}{l}\text { College of } \\
\text { Engineering }\end{array}$ & $\begin{array}{l}\text { Faculty of HEI College of } \\
\text { Engineering demonstrate } \\
\text { key performance and } \\
\text { accountability to ensure } \\
\text { their students' success in } \\
\text { the job market }\end{array}$
\end{tabular}

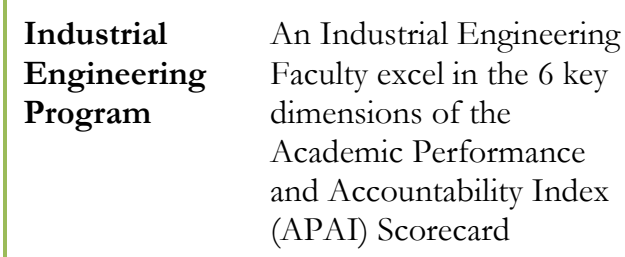

\begin{tabular}{|l|c|c|}
\hline $\begin{array}{l}\text { Dimensions of Performance and } \\
\text { Accountability }\end{array}$ & Weights & $\begin{array}{l}\text { Overall } \\
\text { Weighted } \\
\text { Score }\end{array}$ \\
\hline Course Evaluations Index (CEI) & 10 & 8.0 \\
\hline Student Competencies Index (SCI) & 20 & 15.0 \\
\hline Quality Efforts Contribution Index (QECI) & 15 & 9.75 \\
\hline Research Contributions Index (RCI) & 20 & 15.0 \\
\hline Administrative Work Contribution Index (AWCI) & 15 & 7.5 \\
\hline Societal Responsibility Contribution Index (SRCI) & 15 & 6.0 \\
\hline $\begin{array}{l}\text { Academic Performance and } \\
\text { Accountability Index (APAI) Scorecard }\end{array}$ & $\mathbf{1 0 0}$ & $\mathbf{6 1 . 2 5}$ \\
\hline
\end{tabular}

\section{Mechanical Engineering Individual}

A Mechanical Engineering Faculty excel in the 6 key dimensions of the Academic Performance and Accountability Index (APAI) Scorecard

\begin{tabular}{|l|c|c|}
\hline $\begin{array}{l}\text { Dimensions of Performance and } \\
\text { Accountability }\end{array}$ & Weights & $\begin{array}{c}\text { Overall } \\
\text { Weighted } \\
\text { Score }\end{array}$ \\
\hline Course Evaluations Index (CEI) & 10 & 8.0 \\
\hline Student Competencies Index (SCI) & 20 & 17.0 \\
\hline $\begin{array}{l}\text { Quality Efforts Contribution Index (QECI) } \\
\text { Research Contributions Index (RCI) }\end{array}$ & 15 & 13.75 \\
\hline Administrative Work Contribution Index (AWCI) & 15 & 10.5 \\
\hline $\begin{array}{l}\text { Societal Responsibility Contribution Index (SRCI) } \\
\text { Accountability Index (APAI) Scorecard }\end{array}$ & 15 & 10.0 \\
\hline $\begin{array}{l}\text { Academic Performance and } \\
\text { Ind }\end{array}$ & $\mathbf{7 0}$ & \\
\hline
\end{tabular}


The above Table 6 shows that the cascading of an institutional strategic objective on the $\mathrm{HEI}$ faculty performance and accountability index based on the APAI Index, which shows that the Mechanical Engineering Program Faculty' APAI Index of 77.25 points score has better performance and accountability outcome as compared to the Industrial Engineering Program APAI Index of 61.25 points score or the College of Engineering performance and accountability internal benchmark of 79 points score. On the other hand the overall College of Engineering APAI Index at 79 points score is lower than the institutional SLOC Index of 80 points score. This approach could be used to ensure that the programs' SLOC performances are aligned across the whole institution. It can also be used to determine and compare the accomplishments and achievements of the SLOC of each of the program through the internal comparative benchmarks.

\section{Conclusion}

As indicated in the introduction, the issue of performance and accountability is normally sensitive and qualitative, and this APAS as discussed above provide a more quantitative and justifiable approach in determining the performance and accountability of a faculty. The traditional approach in measuring the $\mathrm{HEl}$ accountability based on external future indicators might be more reactive than proactive to bring about improvements or corrective actions. Under the proposed APAS, it is argued here that:

1. The APAI which serves as a key internal process and people measure of performance and accountability that are measured on a term and annual basis could be an early detector of the final student accomplishment where preventive and proactive actions can be taken during the 4 years education process. These proactive actions will contribute more to the final student outcome measure rather than wait until the end of the 4 year education process when the student has graduated.

2. The APAI can be used to determine the faculty performance and accountability on a termly or annual basis to bring about improvements in the faculty performance, and determine and plan for improvement in areas which are slacking or deficient.

3. The APAI can bring about mutually beneficial information of both the faculty and each of the individual students. If the SLOC Index and the CEI which are key performance areas that relates directly to the student accomplishment are computed on a course by course basis, and for each term, key areas for improvements for the students can be customized and planned for improvements.

4. The APAI here can serve as an effectiveness indicator of a faculty of his/her performance and accountability towards the students' performance over the 4 years period in the HEI system. Inadvertently, this subscribe to the basic tenets of "management through measurement" fundamentals of "what is measured effectively can be managed more efficiently".

While the APAS and the use of the APAI might seem to be a very complicated system, if this system is designed on an electronic platform, these tedious manual tasks when computerized can drastically reduce the time and efforts of each faculty to monitor and measure not only his or her own performance bust also that of the student. As such, it 
is recommended that the APAS should be on an electronic system to make it feasible and justifiable as a strong academic performance and accountability system.

\section{Reference}

Jones, K., (2004), Balanced School Accountability Model: An Alternative to High-Stakes Testing, Phi Delta Kappan, Vol. 85 No. 8, pp. 584 Apr 2004

Jones, K., (Ed.) (2006), Democratic School Accountability: A Model for School Improvement, Lanham, MD: Lowman \& Littlefield Education

Levin, H.M., (1974), A Conceptual Framework for Accountability in Education, The School Review, Vol. 82, No. 3 May 1974, pp 363 - 391, The University of Chicago Press

Linn, R. L., (2003), Accountability: Responsibility and Reasonable Expectations, CRESST, University of Colorado and National Center for Research on Evaluation, UCLA, Los Angeles

Malandra, G. H., (2008), Accountability and learning assessment in the future of Higher Education, On the Horizon, Vol. 16, No. 2, pp. 57 - 71

Middaugh, M.F., (2007), New Directions for Higher Education, No. 140, Winter 2007, Wiley Periodicals Inc., Wiley InterScience

Porter, A. and Chester, M., (2001), Building a High Quality Assessment and Accountability System: The Philadelphia Experience, Paper presented at the $4^{\text {th }}$ annual Brookings Conference, Brookings Institution, Washington D.C.

Teay, S, (2012), Developing and Actioning Strategic Planning in Higher Education Institutions, March 2012. KSU Printing House and AU Digital Press, ISBN 978-974-615-051-4

Teay, S, (2005), AuQS 2000 CQM (Curriculum Quality Management) (1st Edition, 2005), October 2005, Assumption University Digital Press. 


\section{Appendix 1: Academic Performance and Accountability Indices}

\section{(1) Course Qualitative Survey based Evaluations Performance (10 points)}

Band Performance Legend

․ B1 $(0 \%$ to $10 \%)$ Not Reported

ㄱ2 (11 \% to $30 \%)$ Means $2.5-2.99$

․ $\quad$ B3 $(31 \%$ to $50 \%)$ Means $3.0-4.49$

ㄱ B4 (51\% to 65\%) Means $3.5-3.99$

고 (66 \% to $85 \%)$ Means $4.0-4.49$

ㅁ $B 6(85 \%$ to $100 \%)$ Means 4.5 and above

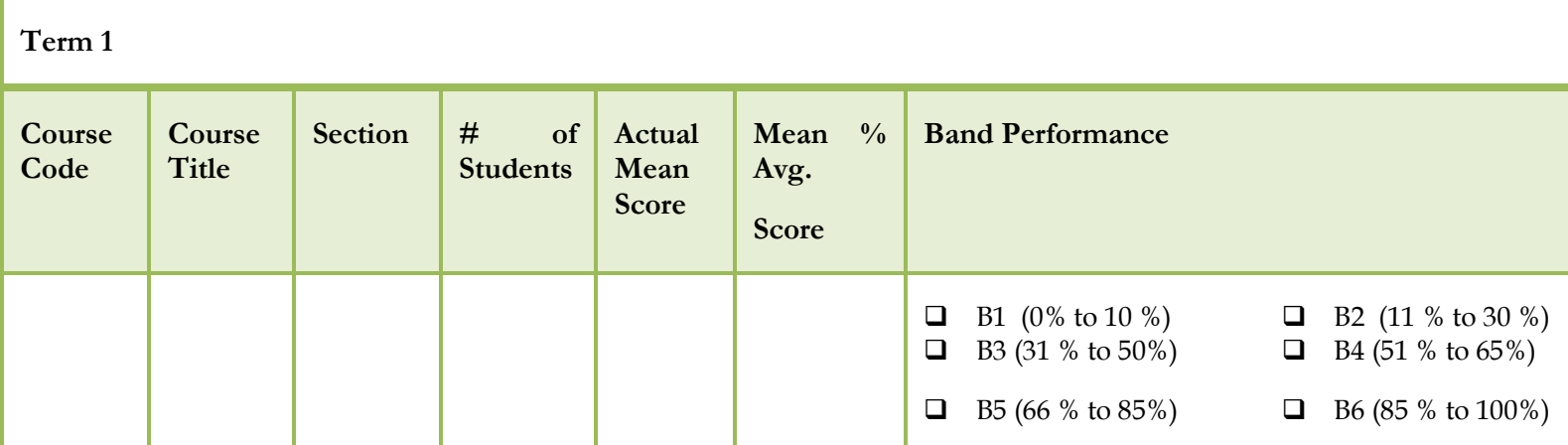

\begin{tabular}{|c|c|c|c|c|c|c|}
\hline & $\begin{array}{l}\text { Actual Mean } \\
\text { Score }\end{array}$ & $\begin{array}{l}\text { Expected } \\
\text { Mean } \\
\text { Score }\end{array}$ & $\begin{array}{l}\text { Gap in } \\
\text { Assessed Mean } \\
\text { Score }\end{array}$ & $\begin{array}{l}\text { Overall } \\
\text { Mean \% Avg. } \\
\text { Score }\end{array}$ & Band Performance & \\
\hline $\begin{array}{l}\text { Annual Overall Course } \\
\text { Evaluation } \\
\text { Performance }\end{array}$ & & & & & $\begin{array}{ll}\text { B } & \text { B1 }(0 \% \text { to } 10 \%) \\
\square & \text { B3 }(31 \% \text { to } 50 \%) \\
& \text { B5 }(66 \% \text { to } 85 \%)\end{array}$ & $\begin{array}{ll}\text { ․ } & \text { B2 }(11 \% \text { to } 30 \%) \\
\text { 口 } & \text { B4 }(51 \% \text { to } 65 \%) \\
\text { ․ } & \text { B6 }(85 \% \text { to } 100 \%)\end{array}$ \\
\hline
\end{tabular}

(2) Course Direct Assessment Student Learning Outcome Performance (20 points)

Band Performance Legend

․ B1 (0\% to $10 \%)$ Unacceptable

․ B2 (11 \% to $30 \%)$ Basic Foundation

口 $\quad$ B3 $(31 \%$ to $50 \%)$ Emergent Proficiency

․ B4 (51 \% to $65 \%)$ Intermediate Proficiency

ㄱ B5 (66 \% to $85 \%)$ Sophisticated Competency

ㄱ B6 (85 \% to 100\%) Advanced Competency

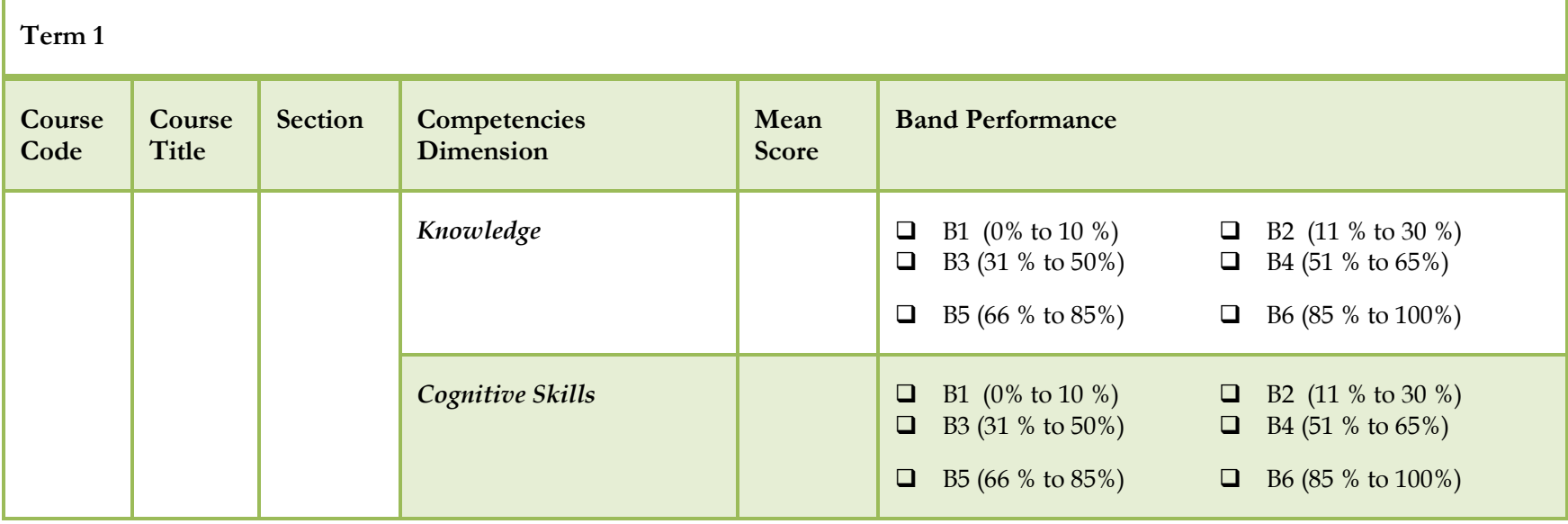




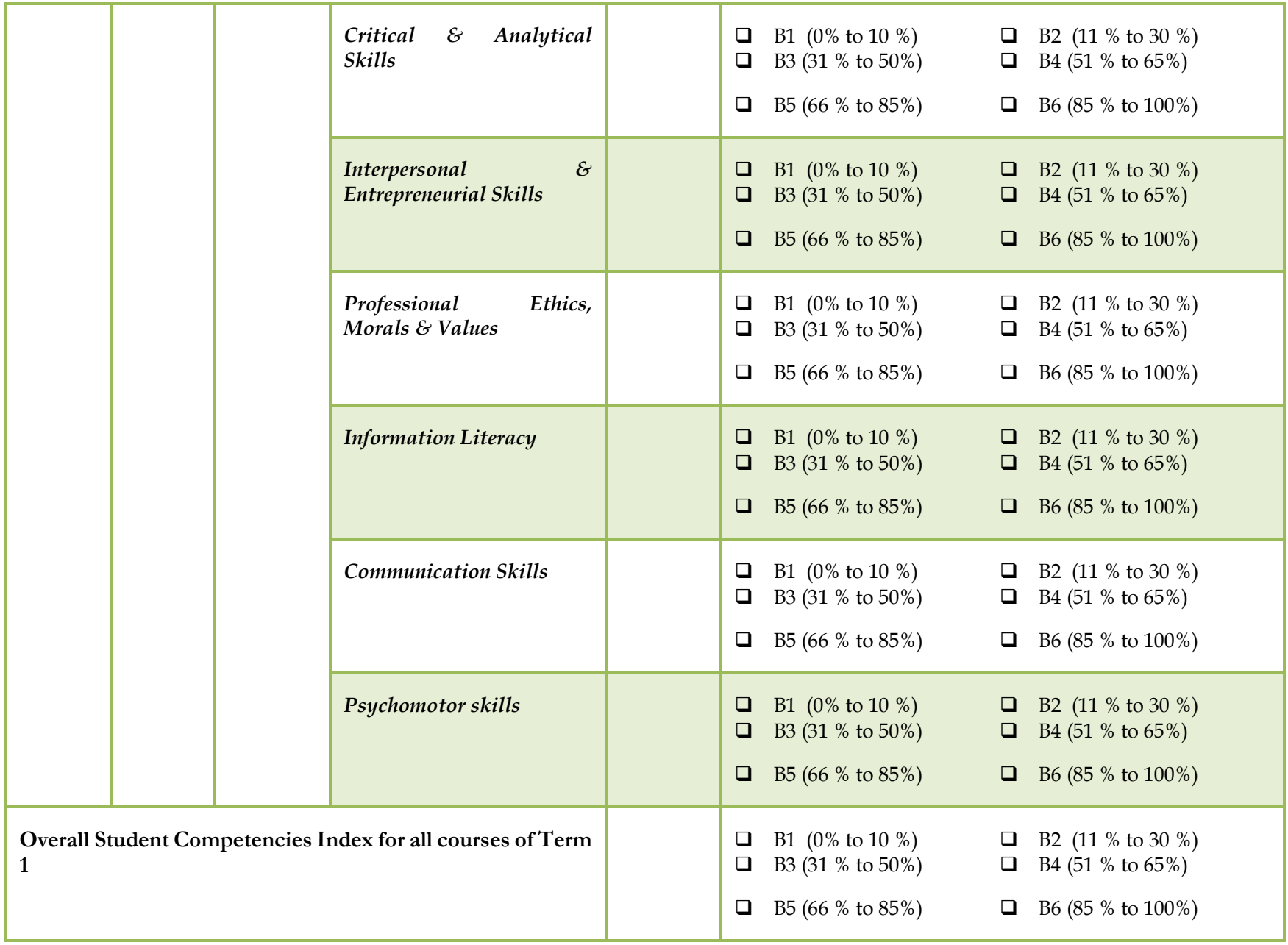

\begin{tabular}{|c|c|c|c|c|c|}
\hline & Term $1 \%$ SCI & Term $2 \%$ SCI & Overall \% SCI & Band Performance & \\
\hline $\begin{array}{l}\text { Overall Student } \\
\text { Competencies Index } \\
\text { for Term } 1 \text { and } 2\end{array}$ & & & & $\begin{array}{ll} & \text { B1 }(0 \% \text { to } 10 \%) \\
& \text { B3 }(31 \% \text { to } 50 \%) \\
& \text { B5 }(66 \% \text { to } 85 \%)\end{array}$ & $\begin{array}{ll}\text { a } & \text { B2 }(11 \% \text { to } 30 \%) \\
\square & \text { B4 }(51 \% \text { to } 65 \%) \\
\square & \text { B6 }(85 \% \text { to } 100 \%)\end{array}$ \\
\hline
\end{tabular}

\section{(3) Quality Efforts Contribution Performance (15 points)}

\section{Band Performance Legend}

․ B1 $(0 \%$ to $10 \%)$ No CS or CR done

․ B3 (31\% to $50 \%)$ CS completed but No CR

ㄱ B5 (66 \% to $85 \%)$ CS and CR completed for 2 years
ㅁ $\quad$ B2 (11 \% to $30 \%)$ Started on CS and CR

口 B4 (51 \% to 65\%) CS completed and CR started

․ B6 (85\% to 100\%) Issues identified and remedied in CR

Term 1 or Term 2

\begin{tabular}{|l|l|l|l|l|l|}
\hline $\begin{array}{l}\text { Course } \\
\text { Code }\end{array}$ & $\begin{array}{l}\text { Course } \\
\text { Title }\end{array}$ & $\begin{array}{l}\text { Course Specs. } \\
\text { CS Score }\end{array}$ & $\begin{array}{l}\text { Course Report } \\
\text { CR Score }\end{array}$ & $\begin{array}{l}\text { CS/CR } \\
\text { Mean Score }\end{array}$ & Band Performance \\
\hline
\end{tabular}




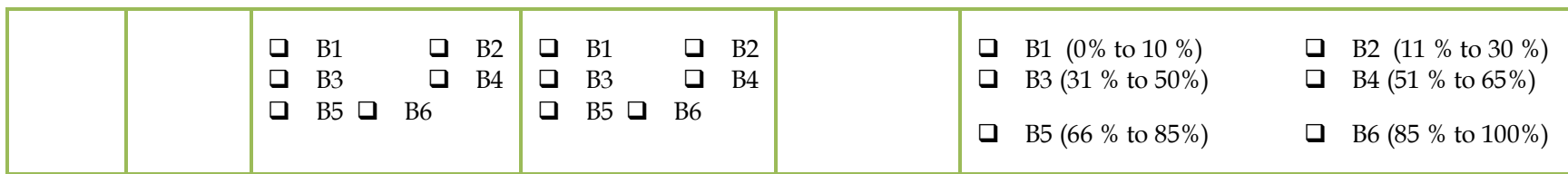

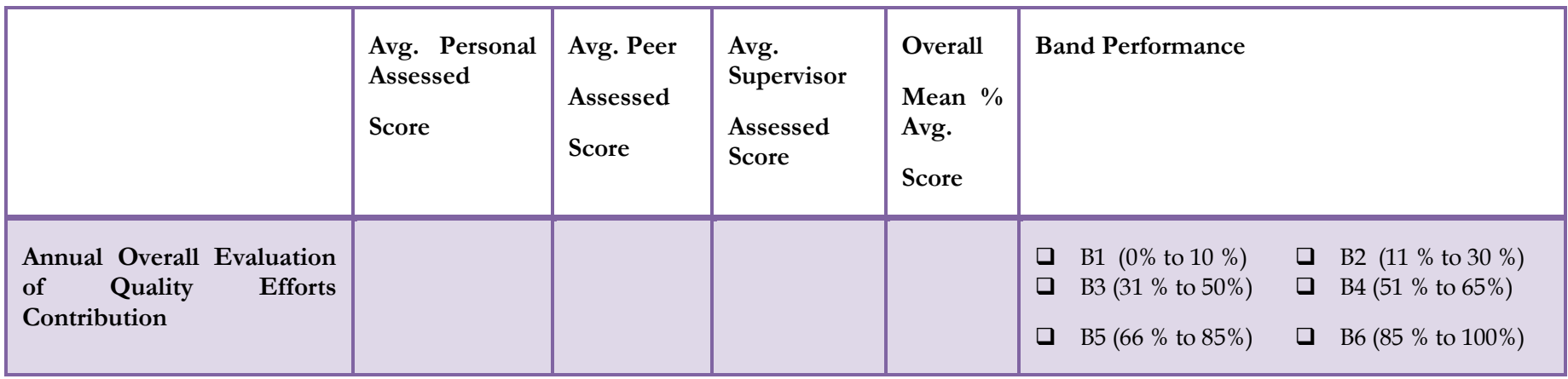

\section{(4) Research Contributions Performance (20 points)}

Band Performance Legend for Authorship Contribution

․ B1 ( $0 \%$ to $10 \%)$ Other supporting author

․ B2 (11 \% to $30 \%)$ Fifth Author

․ B3 (31 \% to 50\%) Fourth Author

구 $34(51 \%$ to $65 \%)$ Third Author

․ B5 (66 \% to $85 \%)$ Second Author

B6 (85\% to $100 \%)$ First Author (100\% for sole author)

Band Performance Legend for Paper Status

․ B1 (0\% to $10 \%)$ Paper In Progress

․ B2 (11 \% to $30 \%)$ Accepted for International Conference

- B 3 (31 \% to 50\%) Publication in Conference Proceedings D B4 (51\% to 65\%) Publication in ISI Journals

․ B5 (66 \% to 85\%) Cited Paper in ISI Journals

․ B6 (85\% to $100 \%)$ Highly Cited Paper in ISI Journals

\begin{tabular}{|c|c|c|c|c|c|c|}
\hline Research Paper & $\begin{array}{l}\text { Authorship } \\
\text { Contribution }\end{array}$ & Paper Status & $\begin{array}{l}\text { Paper Score } \\
(\%)\end{array}$ & Band Performance & & \\
\hline & $\begin{array}{llll}\square & \text { B1 } & \square & \text { B2 } \\
\square & \text { B3 } & \square & \text { B4 } \\
\square & \text { B5 } & \square & \text { B6 }\end{array}$ & $\begin{array}{llll}\square & \mathrm{B} 1 & \square & \mathrm{B} 2 \\
\square & \mathrm{B} 3 & \square & \mathrm{B} 4 \\
\square & \mathrm{B} 5 & \square & \mathrm{B} 6\end{array}$ & & $\begin{array}{ll}\square & \text { B1 }(0 \% \text { to } 10 \%) \\
\square & \text { B3 }(31 \% \text { to } 50 \%) \\
& \text { B5 }(66 \% \text { to } 85 \%)\end{array}$ & $\begin{array}{l}\square \\
\square \\
\square\end{array}$ & $\begin{array}{l}\text { B2 (11 \% to } 30 \%) \\
\text { B4 (51 \% to } 65 \%) \\
\text { B6 (85 \% to } 100 \%)\end{array}$ \\
\hline
\end{tabular}

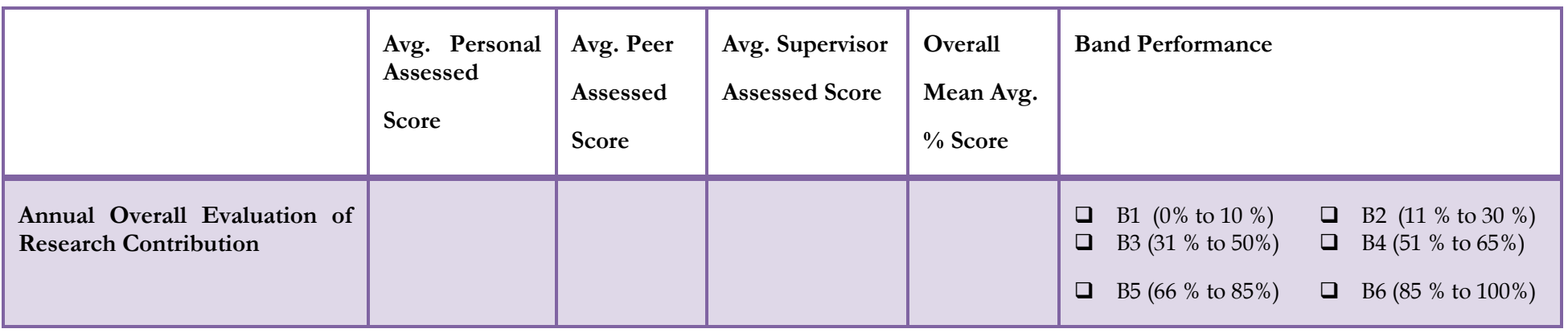

\section{(5) Administrative Work Contribution Performance (15 points)}

Band Performance Legend for work contribution (as reported in Faculty Portfolio. Assessment is on \% of initiative taken for work accomplished) 

B $\quad$ B $(0 \%$ to $10 \%)$ No contribution
그 $2(11 \%$ to $30 \%)$ Minimal contribution
․ B3 (31\% to $50 \%)$ Little contribution
그 (51 \% to $65 \%)$ Average contribution
그 (66 \% to $85 \%)$ Good contribution
․ B6 (85\% to $100 \%)$ Full contribution

Band Performance Legend for Initiative (As reported in Faculty Portfolio. Assessment is on \% of initiative taken for work accomplished)

․ B1 $(0 \%$ to $10 \%)$ No Initiative

․ B2 (11 \% to $30 \%)$ minimal Initiative

- B3 (31\% to 50\%) Little Initiative

ㄱ B4 (51 \% to 65\%) Average Initiative

B $35(66 \%$ to $85 \%)$ Good Initiative

․ B6 (85\% to 100\%) Full Initiative

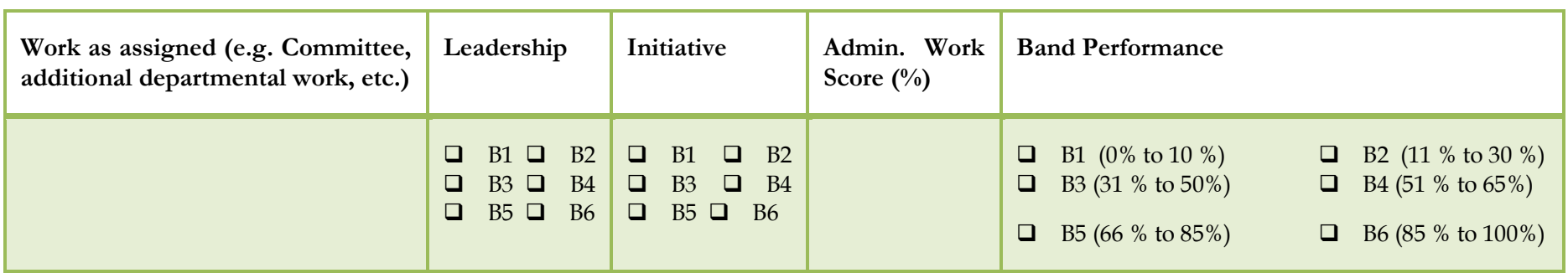

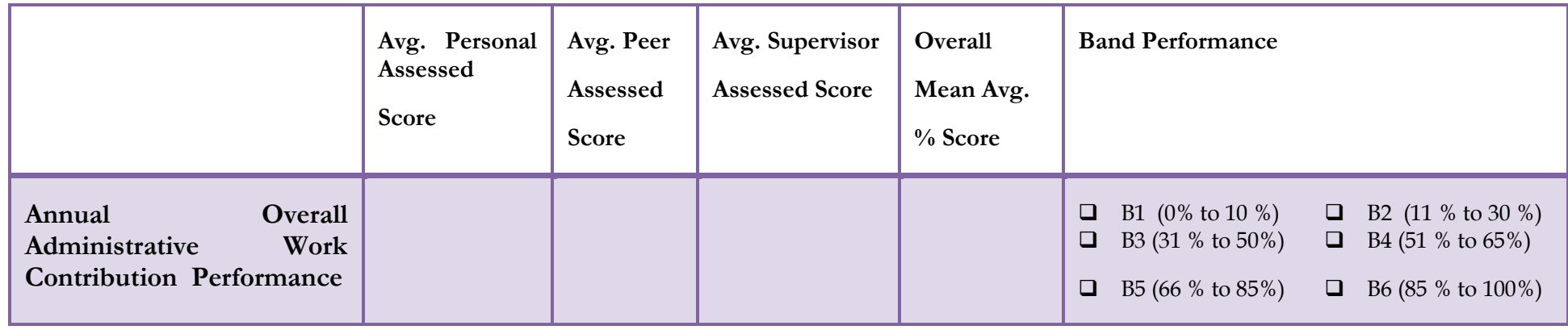

\section{(6) Societal Responsibility Contribution (15 points)}

Band Performance Legend for participation contribution (as reported in Faculty Portfolio. Assessment is on \% of initiative taken for work accomplished)

․ B1 (0\% to $10 \%)$ No participation

B B2 (11 \% to $30 \%)$ Minimal participation

口 $\quad$ B $3(31 \%$ to $50 \%)$ Little c participation

ㄱ B4 (51 \% to $65 \%)$ Average participation

그 $3(66 \%$ to $85 \%)$ Good participation

B B6 (85\% to $100 \%)$ Full participation

Band Performance Legend for Initiative (As reported in Faculty Portfolio. Assessment is on \% of initiative taken for work accomplished)
口 $\mathrm{B} 1(0 \%$ to $10 \%)$ No Initiative
․ B2 (11 \% to $30 \%)$ minimal Initiative
․ B3 (31 \% to 50\%) Little Initiative
ㄱ B4 (51 \% to 65\%) Average Initiative
․ B5 (66 \% to 85\%) Good Initiative
․ B6 (85 \% to 100\%) Full Initiative

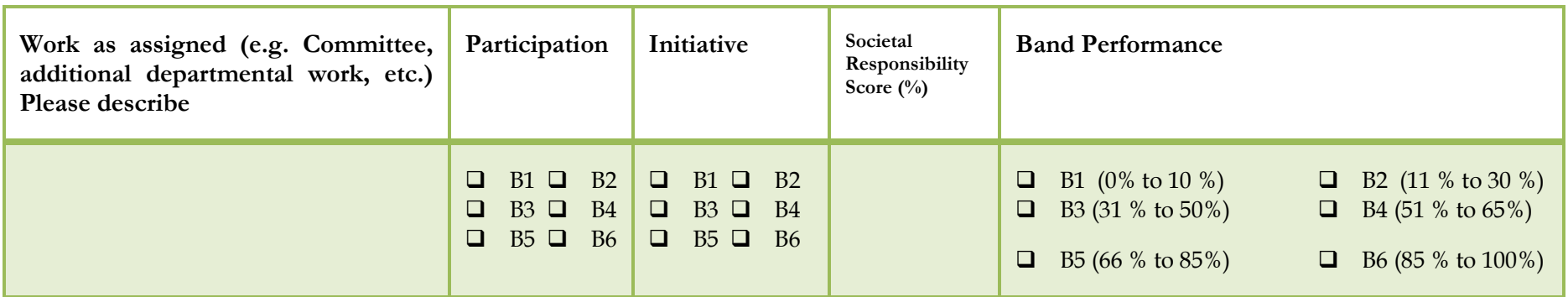




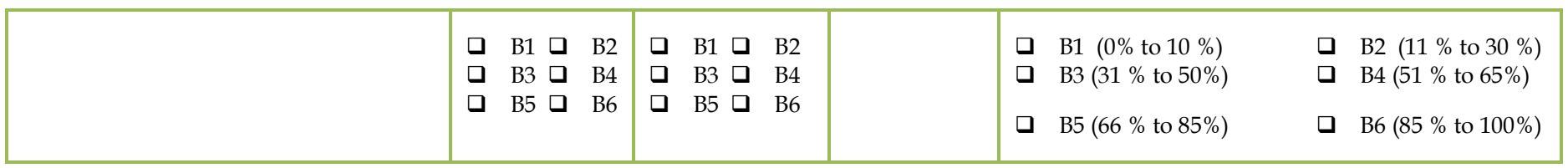

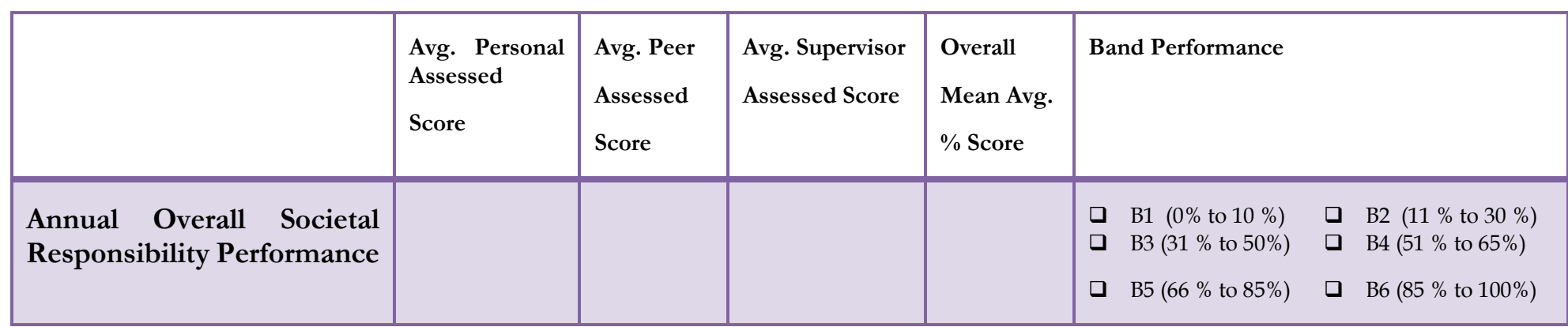

